\title{
Diagnostic criteria for CADASIL in the International Classification of Headache Disorders (ICHD-II): are they appropriate?
}

\author{
Simona Sacco • Diana Degan • Antonio Carolei
}

Received: 13 December 2009/Accepted: 16 February 2010/Published online: 12 March 2010

(C) Springer-Verlag 2010

\begin{abstract}
We reviewed the characteristics of headache in patients with cerebral autosomal dominant arteriopathy with subcortical infarcts and leukoencephalopathy (CADASIL), to verify the appropriateness of the International Classification of Headache Disorders, second edition (ICHD-II) criteria. Available data were found through Medline/PubMed using the keyword "cerebral autosomal dominant arteriopathy with subcortical infarcts and leukoencephalopathy (CADASIL)". The search was restricted to studies published in English in the years between 1993 and 2008. We excluded studies that did not report original data on CADASIL and information regarding the presence of headache. We found 34 studies reporting data on 749 patients overall; 387 (51.7\%) patients had headache. According to the authors' definition, 356 (92\%) patients were reported as having migraine and $31(8 \%)$ as having headache. Of the 356 patients who were defined as migraineurs, $125(35.1 \%)$ had migraine with aura, $7(2 \%)$ migraine without aura, $156(43.8 \%)$ unspecified migraine and $68(19.1 \%)$ had more than one type of migraine. Among the 31 patients reported as suffering from headache, the headache was not further detailed in $18(58.1 \%)$ patients; it was defined as chronic in $6(19.3 \%)$, as resembling migraine with aura in $4(12.9 \%)$, as resembling migraine without aura in $2(6.5 \%)$ and as tension type in 1 (3.2\%) patient. In patients with CADASIL, the headache was usually referred to as migraine and mostly as migraine with aura. However, this referral is formally incorrect since the diagnostic criteria for any type of migraine in the ICHD-II require that the disturbance is not attributed to
\end{abstract}

S. Sacco $(\bowtie) \cdot$ D. Degan · A. Carolei

Department of Neurology, University of L'Aquila, piazzale Salvatore Tommasi 1, 67100 L'Aquila, Italy

e-mail: simona.sacco@yahoo.com another disorder. For this reason, we suggest updating the ICHD-II in relation to CADASIL. Our suggestion is to insert a new category referred to as Headache attributed to genetic disorder including Headache attributed to CADASIL.

Keywords Migraine - Headache C CADASIL . International Classification of Headache Disorders

\section{Introduction}

Cerebral autosomal dominant arteriopathy with subcortical infarcts and leukoencephalopathy (CADASIL) is an adultonset inherited disease due to mutations in the Notch3 gene on chromosome 19p13 [1-3]. These mutations cause an abnormal accumulation of Notch3 in the cytoplasmic membrane of vascular smooth muscle cells both in cerebral and extracerebral vessels, which appear as granular osmiophilic deposits on electron microscopy [4]. The neuroradiological hallmark of the disease is represented by leukoencephalopathy with lacunaes in the basal ganglia, which can become evident at any stage of the disease [4]. The clinical spectrum of CADASIL includes migraine with or without aura, mood disturbances, transient ischemic attacks or strokes (usually lacunar infarcts) and progressive cognitive decline $[1,2,4,5]$. Other disturbances are also reported, including epilepsy, acute reversible encephalopathy and myopathy $[6,7]$.

Headache in patients with CADASIL was first coded, according to the Classification and Diagnostic Criteria for Headache Disorders, Cranial Neuralgias and Facial Pain (ICHD), among headaches associated with other vascular disorders (code 6.9) [8]. Following the ICHD, second edition (ICHD-II), headache in patients with CADASIL is 
coded among the headaches attributed to cranial or cervical vascular disorder (code 6.7.1) on the implicit assumption that a vascular disorder is the cause of the headache [9], an interpretation that, in our opinion, should be reconsidered $[5,10]$.

To verify the appropriateness of the ICHD-II criteria, we deemed it to be of interest to review the studies reporting any headache in patients with CADASIL.

\section{Methods}

Available data for this review were found through Medline/ PubMed using the keyword "cerebral autosomal dominant arteriopathy with subcortical infarcts and leukoencephalopathy (CADASIL)". For our study, we reviewed all studies published in English between 1993 and 2008. All the retrieved studies were examined by the two of us (SS and DD). We excluded studies that did not report original data on CADASIL such as reviews, meta-analyses, comments and editorials. Among studies describing clinical details of patients with CADASIL, we excluded those in which there was no mention of headache or migraine. To exclude overlapping of CADASIL cases by the same research group, we considered what authors wrote in their studies and, where necessary, contacted the corresponding author.

Two of us (SS and DD) evaluated and classified all the reported cases separately. Any possible disagreement was resolved by a third opinion (AC). We maintained the terminology used by the authors in their studies and, consequently, where authors classified the headache according to the ICHD-II we kept their classification and where they used terms not contemplated in the ICHD or ICHD-II we kept their terminology. We also considered whether the headache was the first symptom or whether it was preceded by an ischemic stroke, TIA or other symptoms such as cognitive and psychiatric disturbances.

Mean age \pm standard deviation (SD) was calculated with the method of weighted mean.

\section{Results}

The Medline/PubMed search identified 590 studies; 508 studies were excluded because they did not report clinical data or because there was no mention of headache, and 48 because their data had been already included in other studies by the same authors. We finally reviewed 34 (5.8\%) studies including 16 case reports or letters (Table 1) [1, 5-7, 11-40].

The reviewed studies provided data on 749 patients including 387 (51.7\%) who had headache. According to the authors' definition, $356(92 \%)$ patients were reported as
Table 1 Studies included in the review

\begin{tabular}{|c|c|c|c|c|}
\hline First author & $\begin{array}{l}\text { Year of } \\
\text { publication }\end{array}$ & $\begin{array}{l}\text { Publication } \\
\text { type }\end{array}$ & $\begin{array}{l}\text { Included } \\
\text { patients }(n)\end{array}$ & $\begin{array}{l}\text { Patients with } \\
\text { any headache }(n)\end{array}$ \\
\hline Arboleda & 2002 & OR & 7 & 7 \\
\hline Bergmann & 1996 & OR & 10 & 5 \\
\hline Bohlega & 2007 & OR & 19 & 7 \\
\hline Brulin & 2002 & OR & 50 & 32 \\
\hline Ceroni & 2000 & OR & 8 & 6 \\
\hline Chabriat & 1995 & OR & 45 & 10 \\
\hline Choi & 2006 & OR & 20 & 6 \\
\hline Coto & 2006 & $\mathrm{CR}$ & 1 & 1 \\
\hline Dichgans & 1998 & OR & 102 & 48 \\
\hline Engelter & 2002 & CR & 1 & 1 \\
\hline Finnilà & 2001 & CR & 1 & 1 \\
\hline Hutchinson & 1995 & OR & 10 & 6 \\
\hline Iwatsuki & 2001 & $\mathrm{CR}$ & 3 & 1 \\
\hline Jung & 1995 & OR & 10 & 3 \\
\hline Kim & 2006 & OR & 5 & 1 \\
\hline Malandrini & 2006 & OR & 14 & 4 \\
\hline Mandellos & 2005 & $\mathrm{CR}$ & 4 & 1 \\
\hline Markus & 2002 & OR & 83 & 31 \\
\hline Mellies & 1998 & $\mathrm{CR}$ & 6 & 5 \\
\hline Pantoni & 2004 & $\mathrm{CR}$ & 3 & 3 \\
\hline Peters & 2004 & OR & 80 & 27 \\
\hline Ragno & 2006 & $\mathrm{CR}$ & 6 & 1 \\
\hline Razvi & 2005 & OR & 40 & 26 \\
\hline Rubio & 1997 & $\mathrm{CR}$ & 3 & 3 \\
\hline Rufa & 2004 & $\mathrm{CR}$ & 1 & 1 \\
\hline Sacco & 2008 & $\mathrm{CR}$ & 1 & 1 \\
\hline Schon & 2003 & $\mathrm{CR}$ & 6 & 6 \\
\hline Singhal & 2005 & OR & 112 & 84 \\
\hline Saskia & 2003 & CR & 6 & 3 \\
\hline Sullivan & 1997 & $\mathrm{CR}$ & 5 & 2 \\
\hline Valko & 2007 & CR & 1 & 1 \\
\hline Vahedi & 2004 & OR & 72 & 41 \\
\hline Vérin & 1995 & OR & 13 & 11 \\
\hline Williamson & 1999 & CR & 1 & 1 \\
\hline
\end{tabular}

$O R$ original research, $C R$ case report

having migraine and $31(8 \%)$ as having headache (Table 2).

Out of the 356 patients described as migraineurs, 125 (35.1\%) had migraine with aura, 7 (2\%) migraine without aura, 156 (43.8\%) unspecified migraine, and 68 (19.1\%) had more than one type of migraine (Table 3). Among the 125 patients who had migraine with aura, 24 (19.2\%) had migraine with typical aura, $7(5.6 \%)$ migraine with prolonged aura, $5(4.0 \%)$ familial hemiplegic migraine, 2 (1.6\%) basilar migraine, while in $87(69.6 \%)$ patients the migraine type was not reported. The aura was visual in 10 
Table 2 Overall characteristics of patients with CADASIL

\begin{tabular}{lll}
\hline Characteristics & Migraine & Headache \\
\hline Patients $(n)$ & 356 & 31 \\
Gender $^{\mathrm{a}}(\%)$ & & \\
Men & 36.7 & 36.4 \\
$\quad$ Women & 63.3 & 63.6 \\
Mean age at onset (years) & 32.2 & 38.9 \\
\hline
\end{tabular}

${ }^{a}$ Where available

$(8 \%)$ patients, sensory in $7(5.6 \%)$, motor in $5(4 \%)$ and included multiple symptoms in $25(20 \%)$; the aura type was not specified in $78(62.4 \%)$ patients. Among the 68 patients with more than one type of migraine, $50(73.5 \%)$ had migraine with aura, 38 (55.9\%) migraine without aura, 18 (26.5\%) migraine with aura and without headache, 13 (19.1\%) basilar migraine, 11 (16.2\%) familial hemiplegic migraine, $11(16.2 \%)$ migraine with unspecified atypical aura, $4(5.9 \%)$ acute onset aura without headache, $2(2.9 \%)$ unspecified migraine, $1(1.5 \%)$ migraine with prolonged aura, $1(1.5 \%)$ migraine with acute onset aura, and $1(1.5 \%)$ had status migrainosus (Table 3 ). At the onset of migraine, the mean age \pm SD was $32.2 \pm 13.1$ years.

In the 31 patients reported as having headache, the headache was not further specified in $18(58.1 \%)$ patients, was defined as chronic in $6(19.3 \%)$, as resembling migraine with aura in $4(12.9 \%)$, as resembling migraine without aura in $2(6.5 \%)$, and as tension type headache in 1 (3.2\%) patient. At the onset of headache, mean age \pm SD was $38.9 \pm 16.8$ years.

We also analyzed whether the headache was the first symptom or whether it was preceded by an ischemic stroke, TIA or by other symptoms. After excluding patients for whom data were not reported, 81 patients were described as suffering from migraine and 19 from headache. While 9 of the 81 patients $(11.1 \%)$ had a previous stroke or TIA, migraine was the first symptom in 66 patients $(81.5 \%)$ and in $6(7.4 \%)$ it was preceded by other symptoms. While 3 of the 19 patients $(15.8 \%)$ had a previous stroke or TIA, headache was the first symptom in $14(73.7 \%)$ and in 2 $(10.5 \%)$ it was preceded by other symptoms.

\section{Discussion}

From the 34 reviewed studies, we collected data on 387 patients [1, 5-40]. In none of the cases, the headache was coded according to the ICHD [8] or ICHD-II [9] criteria. The ICHD-II diagnostic criteria for Headache attributed to CADASIL required the following: (A) attacks of migraine with aura, with or without other neurological signs; (B) typical white matter changes on magnetic resonance imaging T2-weighted sequences; (C) diagnostic
Table 3 Distribution of migraine subtypes in patients with CADASIL

\footnotetext{
a Includes one patient diagnosed with migraine accompagnée ${ }^{23}$

${ }^{b}$ Includes two cases of migraine accompagnée $e^{23}$

${ }^{c}$ Unspecified migraine includes cases defined as migraine by authors without any further detail
}

\begin{tabular}{|c|c|c|c|c|}
\hline \multirow[t]{2}{*}{ Migraine subtype } & \multirow[t]{2}{*}{ ICHD code } & \multirow[t]{2}{*}{ ICHD-II code } & \multicolumn{2}{|c|}{ Patients } \\
\hline & & & $n$ & $\%$ \\
\hline Migraine without aura & 1.1 & 1.1 & 7 & 2.0 \\
\hline Migraine with aura & 1.2 & 1.2 & 125 & 35.1 \\
\hline Migraine with typical aura ${ }^{a}$ & 1.2 .1 & 1.2 .1 & 24 & \\
\hline Migraine with prolonged aura & 1.2 .2 & - & 7 & \\
\hline Familial hemiplegic migraine & 1.2 .3 & 1.2 .4 & 5 & \\
\hline Basilar migraine & 1.2 .4 & 1.2 .6 & 2 & \\
\hline Unspecified & - & - & 87 & \\
\hline Unspecified migraine $^{c}$ & - & - & 156 & 43.8 \\
\hline More than one type of migraine & - & - & 68 & 19.1 \\
\hline Migraine with aura ${ }^{\mathrm{b}}$ & 1.2 & 1.2 & 50 & \\
\hline Migraine without aura & 1.1 & 1.1 & 38 & \\
\hline Migraine aura without headache & - & 1.2 .3 & 18 & \\
\hline Basilar migraine & - & 1.2 .6 & 13 & \\
\hline Familial hemiplegic migraine & 1.2 .3 & 1.2 .4 & 11 & \\
\hline Migraine with unspecified atypical aura & - & - & 11 & \\
\hline Acute-onset aura without headache & - & - & 4 & \\
\hline Unspecified migraine $^{c}$ & - & - & 2 & \\
\hline Migraine with prolonged aura & 1.2 .2 & - & 1 & \\
\hline Migraine with acute-onset aura & - & - & 1 & \\
\hline Status migrainosus & - & 1.5 .2 & 1 & \\
\hline
\end{tabular}


Table 4 Proposal for a new classification of headache in patients with CADASIL based on available data

15 Headache attributed to genetic disorder

15.1 Headache attributed to CADASIL

15.1.1 Migraine without aura attributed to CADASIL

15.1.2 Migraine with aura attributed to CADASIL

15.1.2.1 Typical aura with migraine headache

15.1.2.2 Typical aura without headache

15.1.2.3 Hemiplegic migraine

15.1.2.4 Basilar-type migraine

15.1.3 Complications of migraine attributed to CADASIL

15.1.3.1 Status migrainosus

15.1.3.2 Persistent aura without infarction

15.1.5 Unspecified headache

15.2 Headache attributed to other genetic disorders ${ }^{\mathrm{a}}$

a This category is to be expanded and detailed confirmation from skin biopsy evidence or genetic testing (Notch3 mutations) [9]. The coding of headache according to the ICHD or ICHD-II criteria might not have been done due to the paucity of details reported in the previous and present classification. Had authors correctly applied the ICHD-II criteria, patients with CADASIL would have been diagnosed as suffering from headache attributed to CADASIL without any further detail. In the reviewed studies, we found that $51.7 \%$ of patients with CADASIL were reported to have suffered from headache. Anyhow, despite that headache represents one of the major clinical features of CADASIL, we cannot exclude that some patients suffered from a primary headache. Besides, based on age of onset and clinical characteristics of the headache in CADASIL resembling those of some primary headaches, it was not possible to establish the proportion of primary headaches in the same patients. The headache in patients
Table 5 Proposed diagnostic criteria for the new category of headache attributed to genetic disorder
15.1 Headache attributed to CADASIL

A. Attacks of headache with or without neurological symptoms

B. Typical white matter changes on MRI $\left(\mathrm{T}_{2} \mathrm{~W}\right)$

C. Diagnostic confirmation from skin biopsy evidence or genetic testing (Notch 3 mutations)

15.1.1 Migraine without aura attributed to CADASIL

A. Attacks of headache fulfilling criteria A-D for 1.1 Migraine without aura

B. Attributed to CADASIL

15.1.2 Migraine with aura attributed to CADASIL

A. Attacks of headache fulfilling criteria A and B for 1.2 Migraine with aura

B. Attributed to CADASIL

15.1.2.1 Typical aura with migraine headache attributed to CADASIL

A. Attacks of headache fulfilling criteria A-D for 1.2.1 Typical aura with migraine headache

B. Attributed to CADASIL

15.1.2.2 Typical aura without headache attributed to CADASIL

A. Attacks of headache fulfilling criteria A-D for 1.2.3 Typical aura without headache

B. Attributed to CADASIL

15.1.2.3 Hemiplegic migraine attributed to CADASIL

A. Attacks of headache fulfilling criteria A-C for 1.2.5 Sporadic hemiplegic migraine

B. Attributed to CADASIL

15.1.2.4 Basilar-type migraine attributed to CADASIL

A. Attacks of headache fulfilling criteria A-D for 1.2.6 Basilar-type migraine

B. Attributed to CADASIL

15.1.3.1 Status migrainosus attributed to CADASIL

A. Attacks of headache fulfilling criteria A and B for 1.5.2 Status migrainosus

B. Attributed to CADASIL

15.1.3.2 Persistent aura without infarction attributed to CADASIL

A. Attacks of headache fulfilling criterion A for 1.5.3 Persistent aura without infarction

B. Attributed to CADASIL

15.1.5 Unspecified headache

A. Headache is or was present

B. Not enough information to classify the headache in a patient otherwise diagnosed with CADASIL 
with CADASIL was more frequently and clearly defined as migraine and the majority of the migrainous patients were reported as suffering from migraine with aura (35.1\%). Formally, this codification was inappropriate since diagnostic criteria for any type of migraine in the ICHD-II require that the disturbance is not attributed to another disorder. If the classification of CADASIL in the ICHD-II was not revised, clinicians will be induced to commit a formal error defining the headache as migraine or omit useful clinical details attributing the headache to CADASIL without giving any further characteristic. As much as 31 cases were diagnosed with disturbance other than migraine; in those cases, the authors used a generic terminology and possibly included patients suffering from primary headaches such as tension-type headache.

The inclusion of headache in CADASIL, in chapter 6 of ICHD-II, among Headache attributed to cranial or cervical vascular disorder, implies that the headache is caused by a vascular disease. This implication may rely on two possibilities: the former is that the headache in CADASIL might be considered secondary to the presence of an organic vascular lesion and the latter is that a disorder of the vascular system might be considered as the common underlying pathogenic mechanism that causes both headache and stroke. Referring to the former possibility, in CADASIL, the headache is usually the first symptom of the disease $(73.7-81.5 \%$ according to reviewed data) preceding the onset of stroke or TIA. Moreover, a diagnosis of secondary headache is usually evident only when the headache resolves or greatly improves within a specified time interval after its onset or after the acute phase of the vascular disorder; however, this evolution is not reported in patients with CADASIL since the headache persists across the years. Consequently, for all the above reported reasons, this possibility is unlikely. Referring to the latter possibility, we have to consider that the underlying pathology in CADASIL is represented by an angiopathy with a unique type of ultrastructural basal lamina deposits and by degeneration of vascular smooth muscle cells, which are the major source of the Notch3 expression. The evidence for a functional impairment of vascular smooth cells is in line with this latter hypothesis [41] and consequently the pathogenic assumption reported in the ICHD-II is correct. However, we would underscore that the primary mechanism is not represented by the vascular damage, but by the genetic alteration in the Notch 3 expression. For all these reasons, we suggest considering the possibility of revising the ICHD-II when referring to CADASIL. Specifically, we suggest adding a new category that could be named Headache attributed to genetic disorder including Headache attributed to CADASIL (Table 4). The new category might include also other genetic diseases in which headache represents a major clinical feature. Moreover, the new category should also report subtypes according to specific clinical details to allow the precise characterization of headache in the single patient (Table 4). The proposed diagnostic criteria for headache attributed to CADASIL are reported in Table 5. If our proposal is shared by the experts in the field, we think that it shall be easier from now on to characterize patients with CADASIL uniformly and that a good step forward will be realized.

\section{Conflict of interest None.}

\section{References}

1. Chabriat H, Vahedi K, Iba-Zizen MT, Joutel A, Nibbio A, Nagy TG, Krebs MO, Julien J, Dubois B, Ducrocq X, Levasseur M, Homeyer P, Mas JL, Lyon-Caen O, Tournier Lasserve E, Bousser MG (1995) Clinical spectrum of CADASIL: a study of 7 families. Cerebral autosomal dominant arteriopathy with subcortical infarcts and leukoencephalopathy. Lancet 346:934-939

2. Joutel A, Corpechot C, Ducros A, Vahedi K, Chabriat H, Mouton $\mathrm{P}$, Alamowitch S, Domenga V, Cécillion M, Marechai E, Maciazek J, Vayssiere C, Cruaud C, Cabanis EA, Ruchoux MM, Weissenbach J, Bach JF, Bousser MG, Tournier-Lasserve E (1996) Notch 3 mutations in CADASIL, a hereditary adult-onset condition causing stroke and dementia. Nature 383:707-710

3. Sacco S, Olivieri L, Bastianello S, Carolei A (2006) Comorbid neuropathologies in migraine. J Headache Pain 7:222-230

4. Chabriat H, Joutel A, Dichgans M, Tournier-Lasserve E, Bousser MG (2009) CADASIL. Lancet Neurol 8:643-653

5. Vahedi K, Chabriat H, Levy C, Joutel A, Tournier-Lasserve E, Bousser MG (2004) Migraine with aura and brain magnetic resonance imaging abnormalities in patients with CADASIL. Arch Neurol 61:1237-1240

6. Schon F, Martin RJ, Prevett M, Clough C, Enevoldson TP, Markus HS (2003) "CADASIL coma": an underdiagnosed acute encephalopathy. J Neurol Neurosurg Psychiatry 74:249-252

7. Valko PO, Siccoli MM, Schiller A, Wieser HG, Jung HH (2007) Non-convulsive status epilepticus causing focal neurological deficits in CADASIL. J Neurol Neurosurg Psychiatry 78:12871289

8. Headache Classification Committee of the International Headache Society (1988) Classification and diagnostic criteria for headache disorders, cranial neuralgias and facial pain. Cephalalgia 8:1-96

9. Headache Classification Subcommittee of the International Headache Society (2004) The international headache classification of headache disorders, 2nd edn. Cephalalgia 24(Suppl 1):9160

10. Sacco S, Carolei A (2007) Migraine attributed to genetic disorder. Funct Neurol 22:117-118

11. Arboleda-Velasquez JF, Lopera F, Lopez E, Frosch MP, Sepulveda-Falla D, Gutierrez JE, Vargas S, Medina M, Martinez de Arrieta C, Lebo RV, Slaugenhaupt SA, Betensky RA, Villegas A, Arcos-Burgos M, Rivera D, Restrepo JC, Kosik KS (2002) C455R notc3 mutation in a Colombian CADASIL kindred with early onset of stroke. Neurology 59:277-279

12. Bergman M, Ebke M, Yuan Y, Brück W, Mugler M, Schwendemann G (1996) Cerebral autosomal dominant arteriopathy with subcortical infarcts and leukoencephalopathy (CADASIL): a 
morphological study of a German family. Acta Neuropathol 92:341-350

13. Bohlega S, Al Shubili A, Alreshaid A, Alkhairallah T, AlSous MW, Farah S, Abu-Amero KK (2007) CADASIL in Arabs: clinical and genetic findings. BMC Med Genet 8:67

14. Brulin P, Godfraind C, Leteurtre E, Ruchoux MM (2002) Morphometric analysis of ultrastructural vascular changes in CADASIL: analysis of 50 skin biopsy specimens and pathogenetic implications. Acta Neuropathol 104:241-248

15. Ceroni M, Poloni TE, Tonietti S, Fabozzi D, Uggetti C, Frediani F, Simonetti F, Malaspina A, Alimonti D, Celano M, Ferrari M, Carrera P (2000) Migraine with aura and white matter abnormalities: Notch3 mutation. Neurology 54:1869-1871

16. Choi JC, Kang SY, Kang JH, Park JK (2006) Intracerebral hemorrhages in CADASIL. Neurology 67:2042-2044

17. Coto E, Menéndez M, Navarro R, Garcia-Castro M, Alvarez V (2006) A new de novo Notch3 mutation causing CADASIL. Eur J Neurol 13:628-631

18. Dichgans M, Mayer M, Uttner I, Brüning R, Müller-Höcker J, Rungger G, Ebke M, Klockgether T, Gasser T (1998) The phenotypic spectrum of CADASIL: clinical findings in 102 cases. Ann Neurol 44:731-739

19. Engelter ST, Rueegg S, Kirsch EC, Fluri F, Probst A, Steck AJ, Lyrer PA (2002) CADASIL mimicking primary angiitis of the central nervous system. Arch Neurol 59:1480-1483

20. Finnilä S, Tuisku S, Herva R (2001) A novel mitochondrial DNA mutation and a mutation in the Notch3 gene in a patient with myopathy and CADASIL. J Mol Med 79:641-647

21. Hutchinson M, O'Riordan J, Javed M, Quin E, Macerlaine D, Wilcox T, Parfrey N, Nagy TG, Tournier-Lasserve E (1995) Familial hemiplegic migraine and autosomal dominant arteriopathy with leukoencephalopathy (CADASIL). Ann Neurol 38:817-824

22. Iwatsuki K, Murakami T, Manabe Y, Narai H, Warita H, Hayashi T, Abe K (2001) Two cases of Japanese CADASIL with corpus callosum lesion. Tohoku J Exp Med 195:135-140

23. Jung H, Bassetti C, Tournier-Lasserve E, Vahedi K, Arnaboldi M, Arifi VB, Burgunder JM (1995) Cerebral autosomal dominant arteriopathy with subcortical infarcts and leukoencephalopathy: a clinicopathological and genetic study of a Swiss family. J Neurol Neurosurg Psychiatry 59:138-143

24. Kim Y, Kim JS, Kim G, No YJ, Yoo HW (2006) Two novel mutations of the NOTCH3 gene in Korean patients with CADASIL. Mutat Res 593:116-120

25. Lesnik Oberstein SA, van den Boom R, Middelkoop HA, Ferrari $\mathrm{MD}$, Knaap YM, van Houwelingen $\mathrm{HC}$, Breuning $\mathrm{MH}$, van Buchem MA, Haan J (2003) Incipient CADASIL. Arch Neurol 60:707-712

26. Malandrini A, Carrera P, Palmeri S, Cavallaro T, Fabrizi GM, Villanova M, Fattaposta M, Vismara L, Brancolini V, Tanganelli P, Calì A, Morocutti C, Zeviani M, Ferrari M, Guazzi GC (1996) Clinicopathological and genetic studies of two further Italian families with cerebral autosomal dominant arteriopathy. Acta Neuropathol 92:115-122

27. Mandellos D, Limbitaki G, Papadimitriou A, Anastasopoulos D (2005) Cerebral autosomal dominant arteriopathy with subcortical infarcts and leukoencephalopathy (CADASIL) in a Greek family. Neurol Sci 26:278-281
28. Markus HS, Martin RJ, Simpson MA, Dong YB, Ali N, Crosby AH, Powell JF (2002) Diagnostic strategies in CADASIL. Neurology 59:1134-1138

29. Mellies JK, Bäumer T, Müller JA, Tournier-Lasserve E, Chabriat H, Knobloch O, Hackelöer HJ, Goebel HH, Wetzig L, Haller P (1998) SPECT study of a German CADASIL family. Neurology 50:1715-1721

30. Pantoni L, Sarti C, Pescini F, Bianchi S, Bartolini L, Nencini P, Basile AM, Lamassa M, Kalaria RN, Dotti MT, Federico A, Inzitari D (2004) Thrombophilic risk factors and unusual clinical features in three Italian CADASIL patients. Eur J Neurol 11:782787

31. Peters N, Herzog J, Opherk C, Dichgans M (2004) A two-year clinical follow-up study in 80 CADASIL subjects: progression patterns and implications for clinical trials. Stroke 35:1603-1608

32. Ragno M, Fabrizi GM, Cacchiò G, Scarcella M, Sirocchi G, Selvaggio F, Taioli F, Ferrarini M, Trojano L (2006) Two novel Italian CADASIL families from Central Italy with mutation CGC-TGC at codon 1006 in the exon 19 Notch3 gene. Neurol Sci 27:252-256

33. Razvi SSM, Davidson R, Bone I, Muir KW (2005) Is inadequate family history a barrier to diagnosis in CADASIL? Acta Neurol Scand 112:323-326

34. Rubio A, Rifkin D, Powers JM, Patel U, Stewart J, Faust P, Goldman JE, Mohr JP, Numaguchi Y, Jensen K (1997) Phenotypic variability of CADASIL and novel morphologic findings. Acta Neuropathol 94:247-254

35. Rufa A, De Stefano N, Dotti MT, Bianchi S, Sicurelli F, Stromillo ML, D'Aniello B, Federico A (2004) Acute unilateral visual loss as the first symptom of cerebral autosomal dominant arteriopathy with subcortical infarcts and leukoencephalopathy. Arch Neurol 61:577-580

36. Sacco S, Rasura M, Cao M, Bozzao A, Carolei A (2009) CADASIL presenting as status migrainosus and persisting aura without infarction. J Headache Pain 10:51-53

37. Singhal S, Rich P, Markus HS (2005) The spatial distribution of MR imaging abnormalities in cerebral autosomal dominant arteriopathy with subcortical infarcts and leukoencephalopathy and their relationship to age and clinical features. Am J Neuroradiol 26:2481-2487

38. Sullivan AA, Teh BT, Jeavons S, Schalling M, Silburn P, Larsson C, Boyle R (1997) Cerebral autosomal dominant arteriopathy with subcortical infarcts and leucoencephalopathy. J Clin Neurosci 4:176-180

39. Vérin M, Rolland Y, Landgraf F, Chabriat H, Bompais B, Michel A, Vahedi K, Martinet JP, Tournier-Lasserve E, Lemaitre MH, Edan G (1995) New phenotype of the cerebral autosomal dominant arteriopathy mapped to chromosome 19: migraine as the prominent clinical feature. J Neurol Neurosurg Psychiatry 59:579-585

40. Williamson EE, Chukwudelunzu FE, Meschia JF, Witte RJ, Dickson DW, Cohen MD (1999) Distinguishing primary angiitis of the central nervous system from cerebral autosomal dominant arteriopathy with subcortical infarcts and leukoencephalopathy. Arthritis Rheum 42:2243-2248

41. Dichgans M (2002) CADASIL: a monogenic condition causing stroke and subcortical vascular dementia. Cerebrovasc Dis 13:37-41 